\title{
SCADA system for agricultural cultivation under a greenhouse prototype
}

\section{Sistema SCADA para cultivo agrícola bajo prototipo de invernadero}

\author{
AC-COLLI, Yajaira Irai †*, MANRIQUE-EK, Josué Abraham, CARDOZO-AGUILAR, Guadalupe and
} DECENA-CHAN, Carlos Alberto

Instituto Tecnológico Superior De Calkiní En El Estado De Campeche, Avenida AH-Canul, Sin Número, San Felipe, 24900 Calkiní, Campeche

ID $1^{\text {st }}$ Author: Yajaira Irai, Ac-Colli / ORC ID: 0000-0003-4237-322X, Researcher ID Thomson: AAV-8309-2021, CVU CONACYT ID: 1148624

ID $1^{\text {st }}$ Co-author: Josué Abraham, Manrique-Ek / ORC ID: 0000-0002-1369-35269727, Researcher ID Thomson: I-58732018, arXiv Author ID: EFYDCI-9MW4UV

ID $2^{\text {nd }}$ Co-author: Guadalupe, Cardozo-Aguilar / ORC ID: 0000-0001-80332280, Researcher ID Thomson: I-5874-2018, arXiv Author ID: TLTSYW-VLXBVS

ID $3^{\text {rd }}$ Co-author: Carlos Alberto, Decena-Chan / ORC ID: 0000-0002-0223-8106, Researcher ID Thomson: AAX-94262021, CVU CONACYT ID: 1155496

DOI: $10.35429 / J T P .2021 .20 .7 .1 .11$

Received July 12, 2021; Accepted October 15, 2021

Abstract

This article presents a proposed model for the acquisition, monitoring and control of parameters using the concept of SCADA. In addition, it will be applied to a greenhouse prototype, in order to monitor the climatological relationships in a crop. The development of this project was approached with an action-research type design, which focuses on solving immediate and everyday problems, building knowledge through practice. The state of the art was reviewed. Subsequently, the existing components and technologies were identified, with the aim of determining the ideal tools for the design of the prototype. Simultaneously, the electronic system of the greenhouse will allow to measure, control, automate and monitor the temperature, humidity and luminosity. To conclude the experimentation, the behaviour of the variables is observed by monitoring the irrigation process of a crop, within the greenhouse prototype.

SCADA, Greenhouse, Control

\section{Resumen}

El presente artículo expone una propuesta de modelo de adquisición, monitoreo y control de parámetros utilizando el concepto de SCADA. Además, será aplicado a un prototipo de invernadero, con el fin de realizar seguimiento de las relaciones climatológicas en un cultivo. El desarrollo de este proyecto se abordó con un diseño de tipo investigación-acción, el cual se centra en resolver problemas cotidianos e inmediatos, construyendo el conocimiento por medio de la práctica. Se procedió a revisar el estado del arte. Posteriormente se identificaron los componentes y las tecnologías existentes, con el objetivo de determinar las herramientas idóneas para el diseño del prototipo. Simultáneamente el sistema electrónico del invernadero permitirá medir, controlar, automatizar y monitorear la temperatura, humedad y luminosidad. Para concluir con la experimentación, el comportamiento de las variables es observado por medio del monitoreo del proceso de riego de un cultivo, dentro del prototipo de invernadero.

SCADA, Invernadero, Control

Citation: AC-COLLI, Yajaira Irai, MANRIQUE-EK, Josué Abraham, CARDOZO-AGUILAR, Guadalupe and DECENACHAN, Carlos Alberto. SCADA system for agricultural cultivation under a greenhouse prototype. Journal of Technological Prototypes. 2021. 7-20: 1-11

\footnotetext{
* Correspondence to Author (email: 5724@itescam.edu.mx)

$\uparrow$ Researcher contributing first author
} 


\section{Introduction}

Throughout the last decades, control, supervision and data acquisition systems, known as SCADA (Supervisory Control and Data Acquisition), have been used in different scientific and technical fields. A SCADA system is understood to be a software application designed to be executed on equipment whose objective is to monitor and control a certain process. Also, to provide communication with field devices (autonomous controllers). Also controlling the process automatically from the computer screen.

Agriculture is considered sensitive to climate change, with its increasingly frequent erratic patterns (climatic uncertainty, droughts, torrential rains, hailstorms and frosts).

This article presents the resolution of an agricultural problem with the interest of giving it an efficient solution through the implementation of a SCADA in greenhouse agriculture.

This type of system is intended to monitor and control the parameters of temperature, humidity and luminosity during the life cycle of a crop of plants and / or vegetables, thus contributing to the agricultural sector and technological development.

\section{Theoretical framework}

Automation as an engineering discipline is broader than a control system. Automation encompasses industrial instrumentation, including field sensors and transmitters, monitoring and control systems, data collection and transmission system, and real-time software applications to monitor and control plant operations or industrial processes.

In industrial processes, the use of measuring equipment facilitates the obtaining of electrical data, but its main disadvantage is that its reading capacity is reduced to few parameters, which is why man, with the help of science and technology, has developed equipment that allows to obtain a myriad of electrical data. This fact, together with the use of control and data acquisition programs (SCADA) has made it possible to carry out large and efficient systems of rational use and energy saving.
The first time that SCADA was used was for applications related to "gas and liquid pipes, the transmission and distribution of electric power and in water distribution systems, for their automatic control and monitoring" according to the author Pérez-López (2014).

To control the process automatically from the computer screen, which is configured by the user and can be easily modified, the SCADA allows communication with field devices (autonomous controllers, programmable automatons, dosing systems, etc.)

Traditional agriculture will hardly reach the $50 \%$ of the harvest in the open field. Parallel to this, controlled agriculture, such as a smart greenhouse, normally harvests $100 \%$ of the seeds.

Protected Agriculture is carried out under conditions in which the farmer can control some environmental factors, this minimizes the impact that climate changes can cause to crops. Its characteristic is the protection against risks to agriculture (climatic, economic risks profitability, market or limitations of productive resources (water or surface)). FAO-SAGARPA, 2007.

Greenhouses are structures of various shapes and sizes, whose purpose is to protect the conditions of temperature and humidity, in addition to providing protection against pests and diseases for the cultivation of plants within a suitable environment and to obtain crops more quickly and during any season of the year, Hernández (2013). Greenhouse cultivation is a production option that protects crops from adverse environmental factors, such as extreme temperatures, intense precipitation, low relative humidity and intense solar radiation (Robledo and Martín, 1988; Jensen and Malter, 1995). Also, with this production system it is possible to have better control of pests and diseases, which helps to increase the quality and quantity of crops (Macias, 2003).

The main crops grown under greenhouse in Mexico are tomatoes, peppers and cucumbers. The habanero pepper can be an alternative crop for greenhouse production, especially in regions where the open field does not develop well, such as the arid and semi-arid regions of Mexico. 
The habanero pepper is a hot climate vegetable, the temperature ranges in which it develops normally are: minimum $10 \circ \mathrm{C}$, maximum $35^{\circ} \mathrm{C}$ and optimal $30^{\circ} \mathrm{C}$. Temperatures below $10^{\circ} \mathrm{C}$ and above $35^{\circ} \mathrm{C}$ limit the development of the crop (Ramírez, 2006).

Optimum relative humidity should be between $50-60 \%$. Very high relative humidity favors the development of aerial diseases and makes fertilization difficult. When humidity and temperature are high, poor flowering, flower drop, misshapen fruit and growth decline occur, these similar effects also occur when relative humidity is low. The most favorable soils for the development of the habanero pepper are those that have good drainage and good moisture retention, with a $\mathrm{pH}$ of 5 to 7.0. In summary, the optimal variables of the habanero pepper are shown in the following table.

\begin{tabular}{|l|l|}
\hline \multicolumn{2}{|l|}{ Optimal requirements for the habanero pepper } \\
\hline Temperature & $25^{\circ} \mathrm{C}$ to $30^{\circ} \mathrm{C}$ \\
\hline pH & 5 to 7.0 \\
\hline Relative humidity & $50 \%$ to $60 \%$ \\
\hline
\end{tabular}

Table 1 Optimal requirements for the habanero pepper Source: Elaboration with data from Ramírez (2006)

\section{Objetive}

Develop a SCADA data acquisition, monitoring and control model applied to a greenhouse prototype monitoring the weather conditions in a habanero pepper crop.

\section{Methodology}

The activities of this project represent the experimental type, since it is based on the constant manipulation of sensors and actuators that will allow the supervision, acquisition, and control of data, which in this case will be the variables of temperature, humidity, light and $\mathrm{pH}$ of the environment of a prototype greenhouse for the cultivation of habanero pepper.

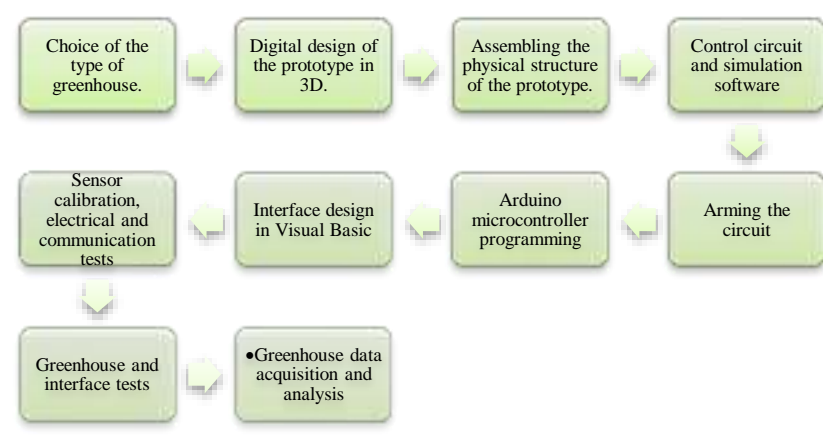

Graph 1 Development stages and project results

\section{Choice of the type of greenhouse}

The design chosen was that of a simple chapel, because thanks to its geometric shape it is easier to build according to the materials planned to be used.

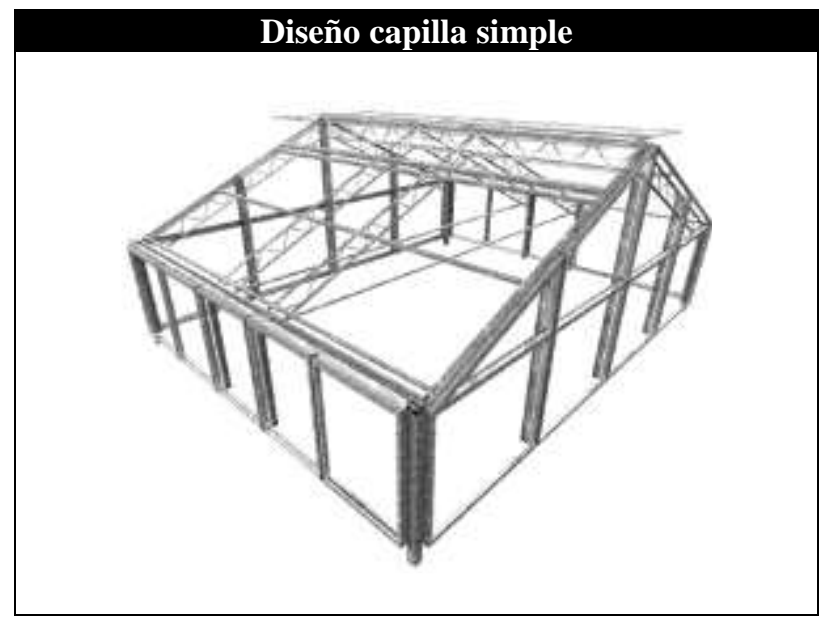

Table 2 Greenhouse design chosen for the prototype

\section{D digital prototype design}

The prototype of the greenhouse is one with a simple chapel, with the following measurements: $1 \mathrm{~m}$ long by $50 \mathrm{~cm}$ wide $\mathrm{x} 60 \mathrm{~cm}$ high. A program was used to carry out the modeling of the structure where the sensors, actuators and control circuits were placed, for this case the computer-aided design and modeling program (SolidWorks) was chosen.

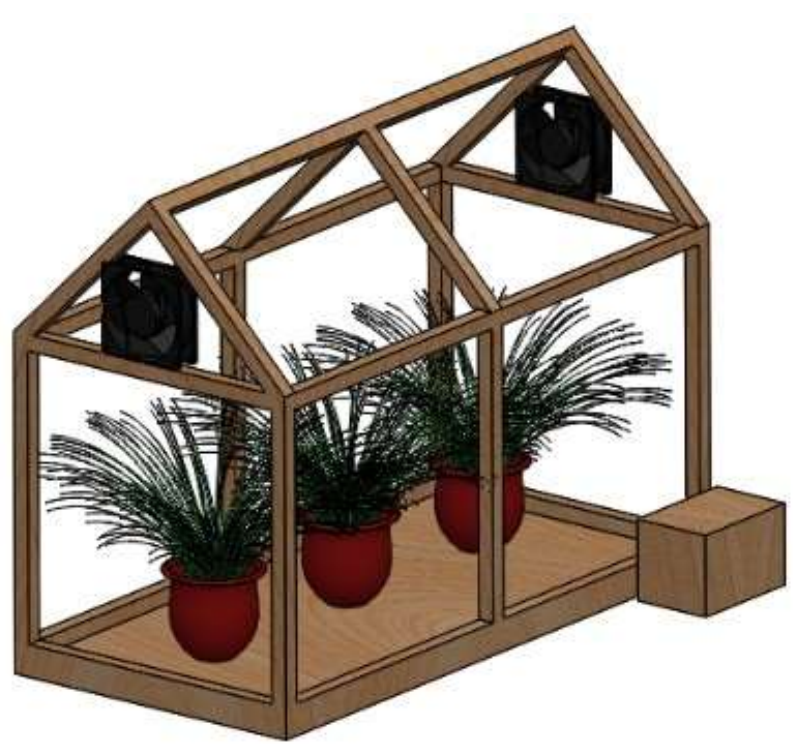

Figure 1 First CAD design of the Greenhouse prototype 


\section{Assembling the physical structure of the prototype}

In the following tables you can see the materials, sensors and actuators that were used in the prototype.

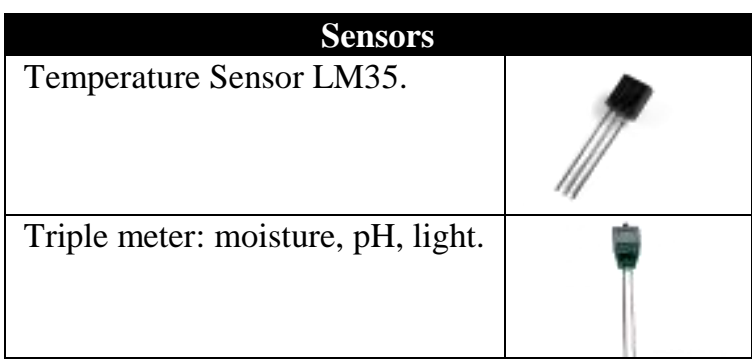

Table 3 Name and image of the sensors used for monitoring variables

\begin{tabular}{|l|l|}
\hline \multicolumn{2}{|c|}{ Actuators } \\
\hline Fans & \\
\hline Water punp & \\
\hline UV light & \\
\hline
\end{tabular}

Table 4 Name and image of the actuators used to control variables

In the following image we can see the tables, and the plywood already cut with the measurements obtained from our 3D design, for the construction of the physical structure. In addition to these materials, nails, silicone rods, and hot silicone were needed.

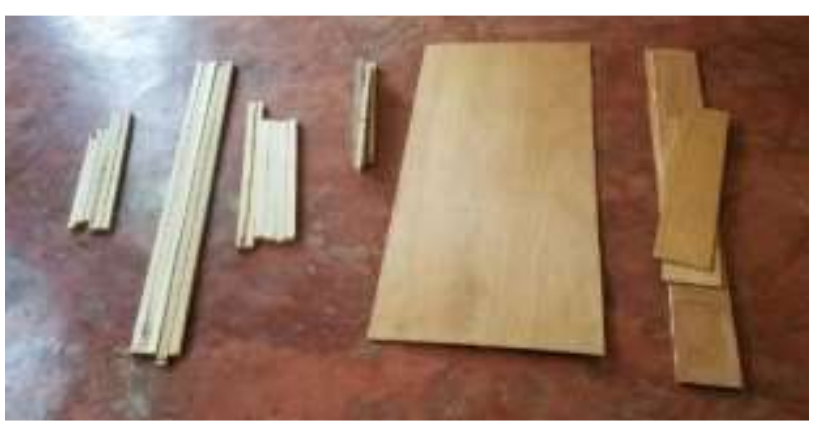

Figure 2 Main materials for the assembly of the prototype. Already measured and trimmed

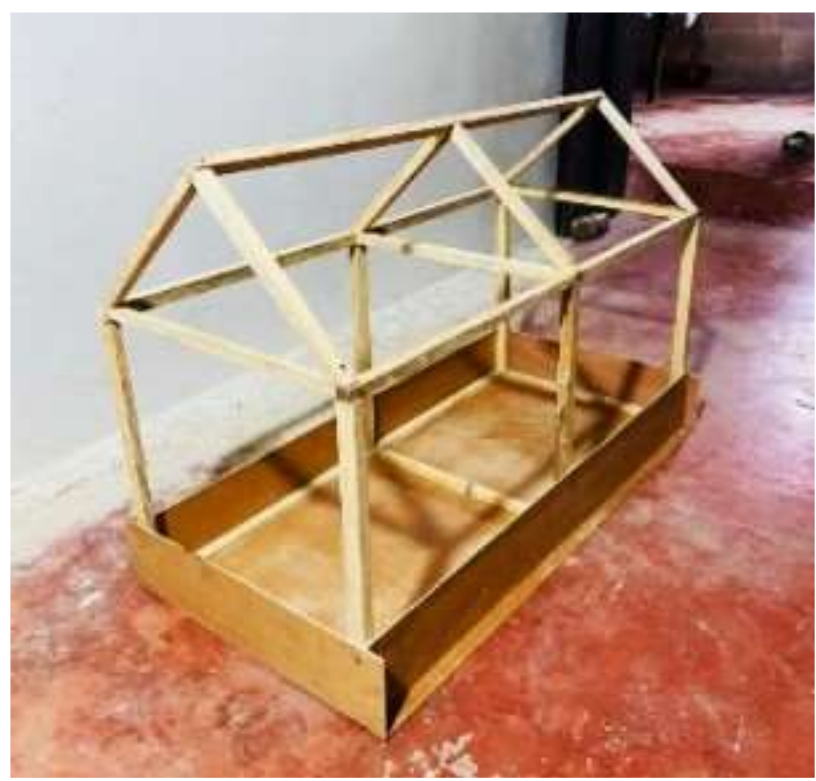

Figure 3 Skeleton and base of our finished prototype

Once the structure was finished, the irrigation system was placed, which consisted of a PVCbased rectangle with holes in the base, which allow dripping by supplying it with water.

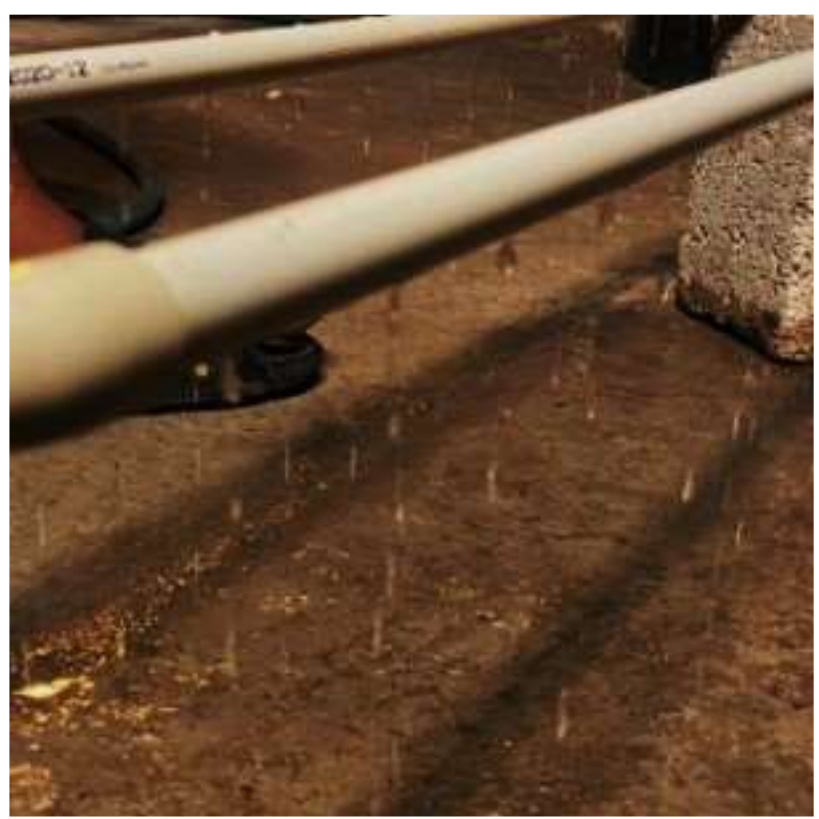

Figurea 4 Drip test results.

Next was the installation of the UV lightbar. The ultraviolet led were soldered one by one to some copper plates glued to a wooden bar. 


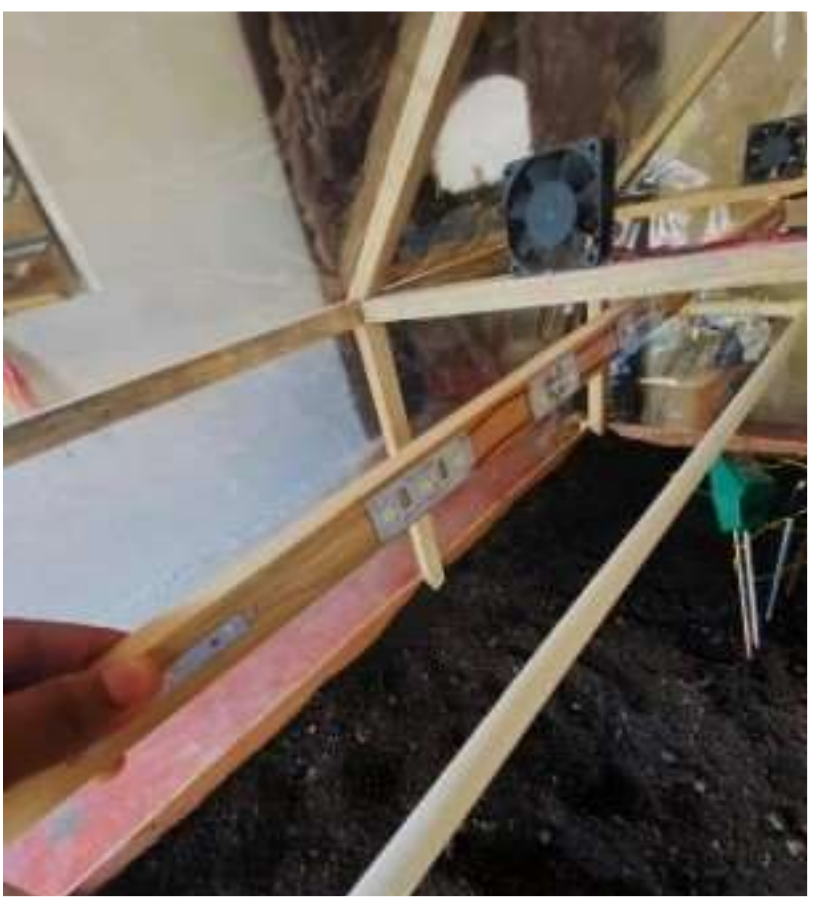

Figure 5 Lights already installed on the roof of our prototype

Once the lights and the irrigation system were in place, the two actuators were installed (the water pump and fans).

As a penultimate step, the sensors were installed, the LM35 under a fan and the triple sensor disassembled, they were placed in different places in the greenhouse. The temperature sensor on the roof of the structure and the electrodes are $5 \mathrm{~cm}$ deep from the base.

As a last step, the walls were sealed and the relevant electrical connections were made. Not without first sowing the habanero pepper seeds.

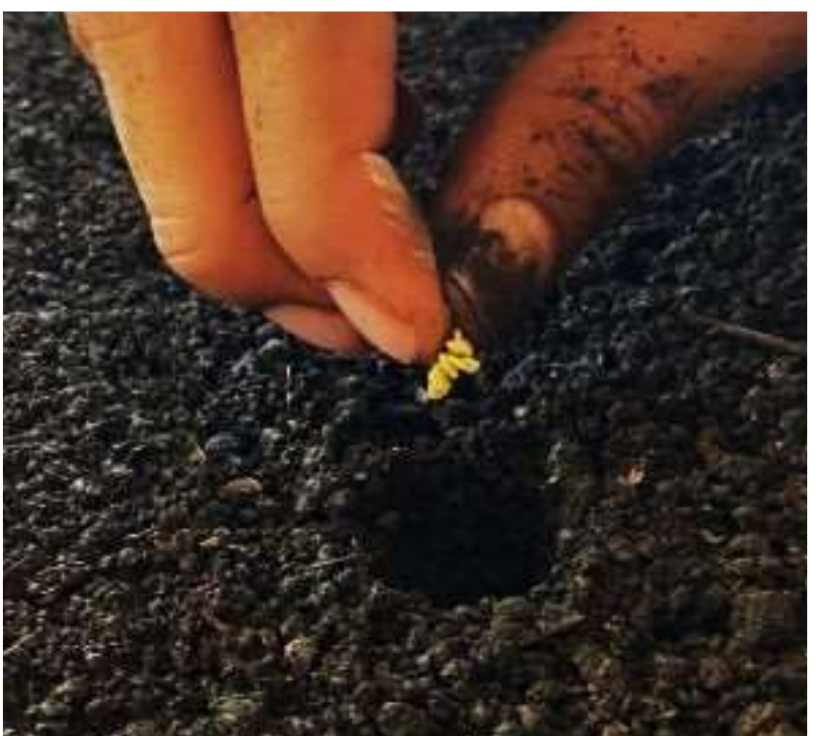

Figure 6 Planting the process of the habanero pepper

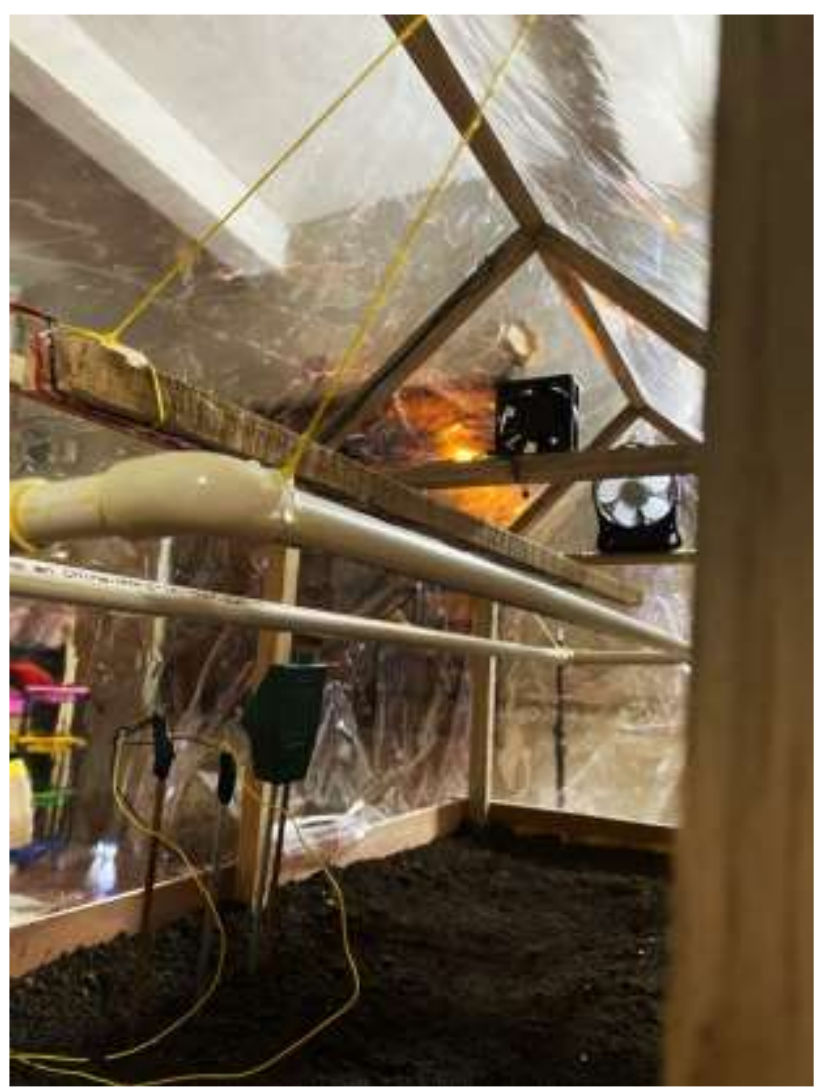

Figure 7 View of the interior of the greenhouse prototype

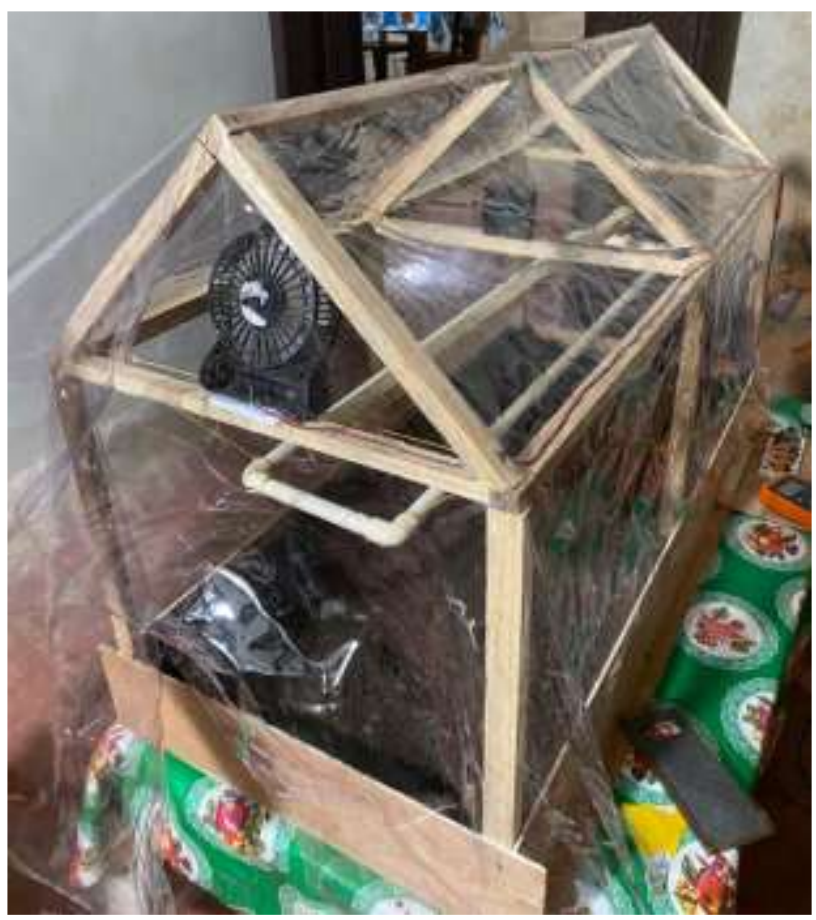

Figure 8 Final view of the greenhouse prototype

\section{Control circuit and simulation software}

The circuit was designed with the help of simulation software for electrical circuits such as Proteus 8. The Arduino microcontroller was used to control the entire system. 


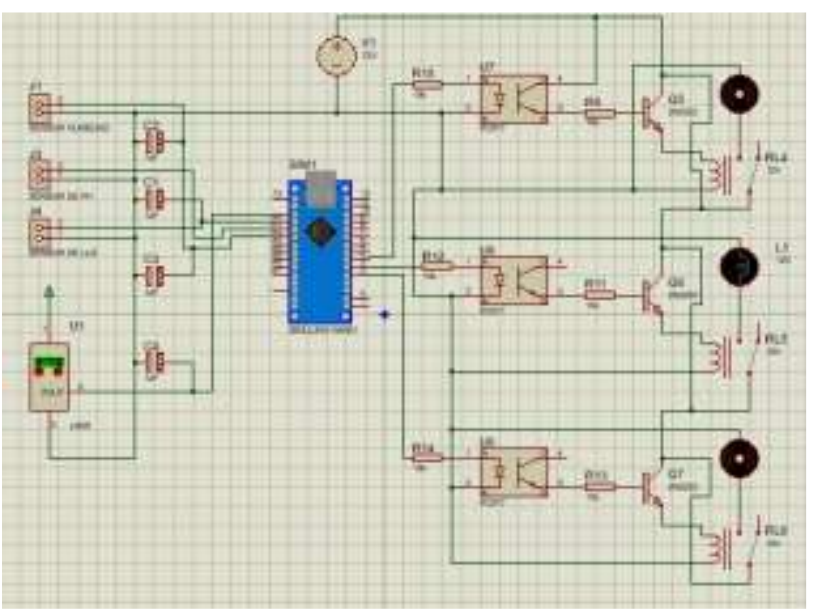

Figure 9 Control circuit, the power part is isolated from the sensors

The power circuit was separated from the control circuit as it is shown in figure 9, the main source is $12 \mathrm{~V}$ and relays are used to activate the actuators because they consume more current than the Arduino supplies. A 2N2222 transistor is used to drive the relay, and an optocoupler is used to isolate the power circuit from the control circuit.

\section{Arming the circuit}

In this activity, the circuit developed in Proteus was assembled. The circuit was mounted on a breadboard and 22 gauge wire type cable was used to join the electronic components with the Arduino. Relays, capacitors, resistors, transistors were used. To read the sensors, they are connected to ground and a small $1 \mathrm{uF}$ capacitor is added to the output of the signal to filter the signal since it presents a lot of noise, as can be seen in the figure, the sensors are connected to the analog inputs of the Arduino.

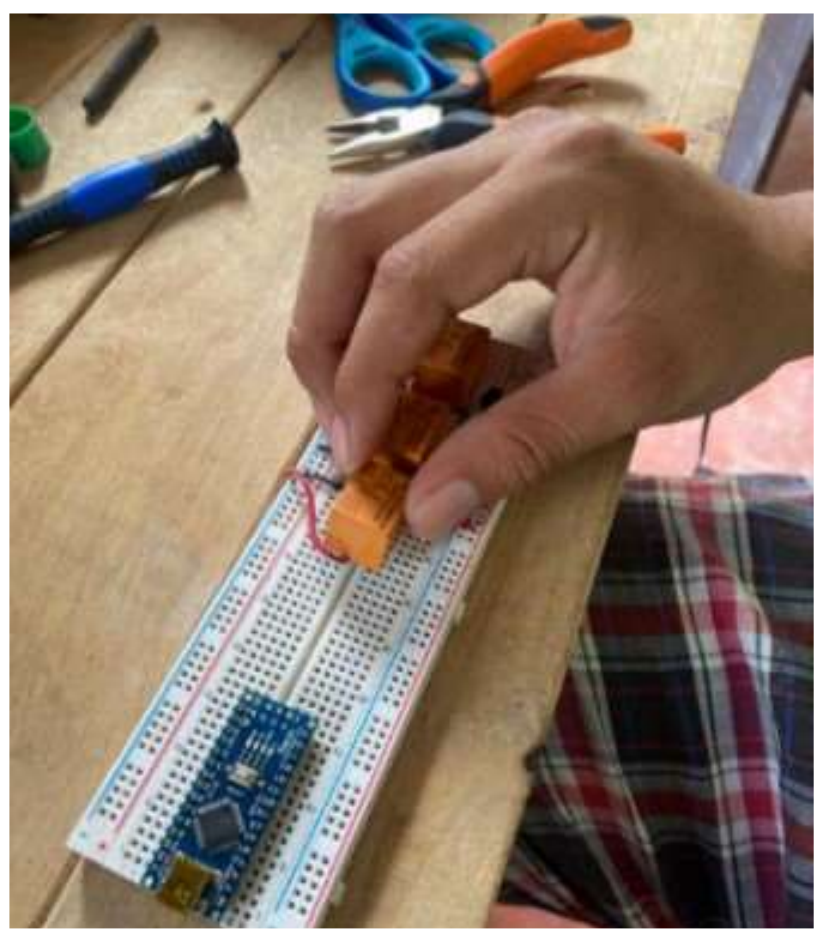

Figure 10 Arming the control circuit

\section{Programming the microcontroller}

The Arduino microcontroller was programmed, looking at the peripherals of the greenhouse circuit. The Arduino's ADCs were configured to adjust the reading voltage as some sensors work with a voltage range lower than the Arduino's $5 \mathrm{~V}$, so sampling at $5 \mathrm{~V}$ would mean wasted bits in signal resolution.

The program will receive a command from the interface and depending on the command it will activate or deactivate the automatic mode, it will have a counter for each actuator in the manual part and in the automatic it will activate the actuator depending on the information from the sensors, then it will send a command to the interface followed by sensor information.

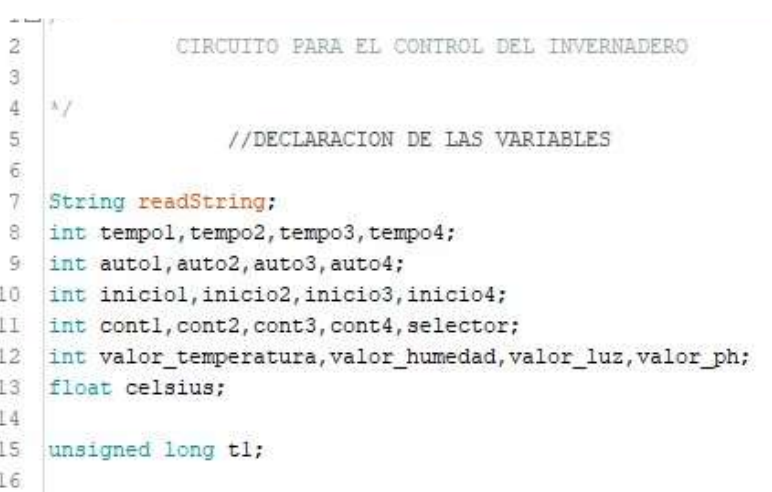

Figure 11 Declaration of the variables 


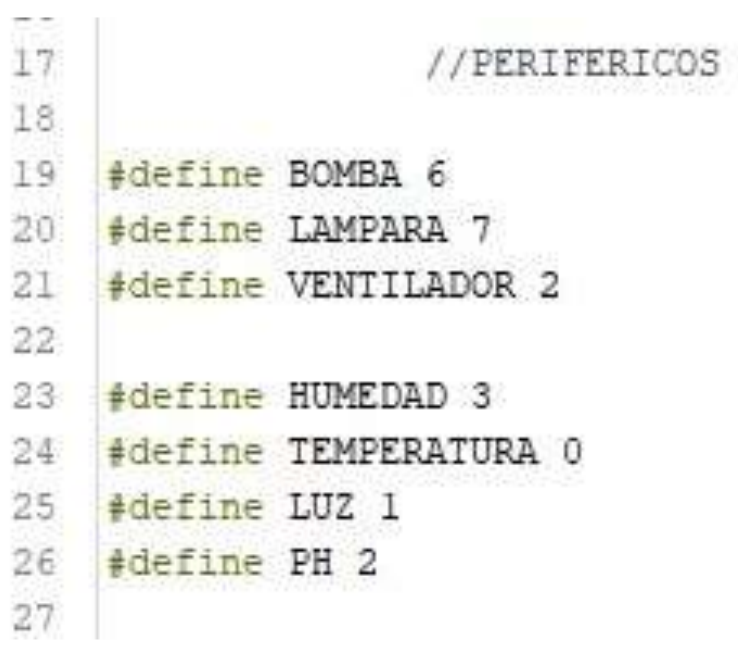

Figure 12 Declaration of peripherals

After the declaration of the labels, the actuators must be configured as digital outputs and initialized the serial port for the communication of the Arduino with the interface, the reference voltage for the analog readings is also configured at $1.1 \mathrm{~V}$, which is the internal reference.

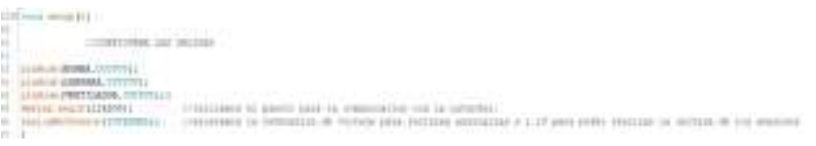

Figure 13 Arduino communication and ports configuration

After configuring the Arduino, it goes to the infinite loop, where the first thing that is done is to receive and process the information from the interface, depending on the command that is identified, it is the action that the microcontroller is going to perform, as we can see in figure 14 .

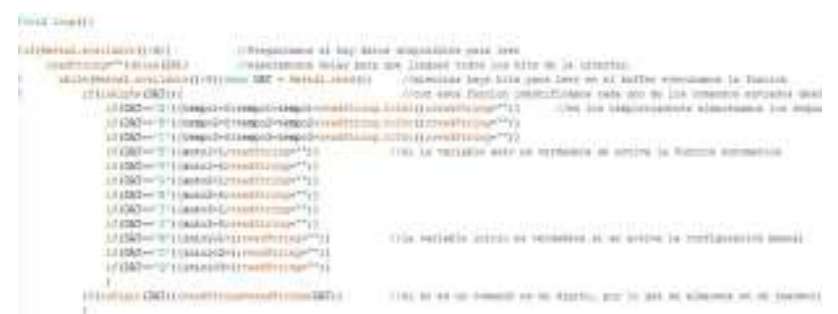

Figure 14 Reading and identification of commands sent from the interface

For the Arduino to send the information from the sensors, it must do it one by one. For this, the selector variable is used, which is basically a counter that selects in an orderly manner which sensor sends information to the interface.

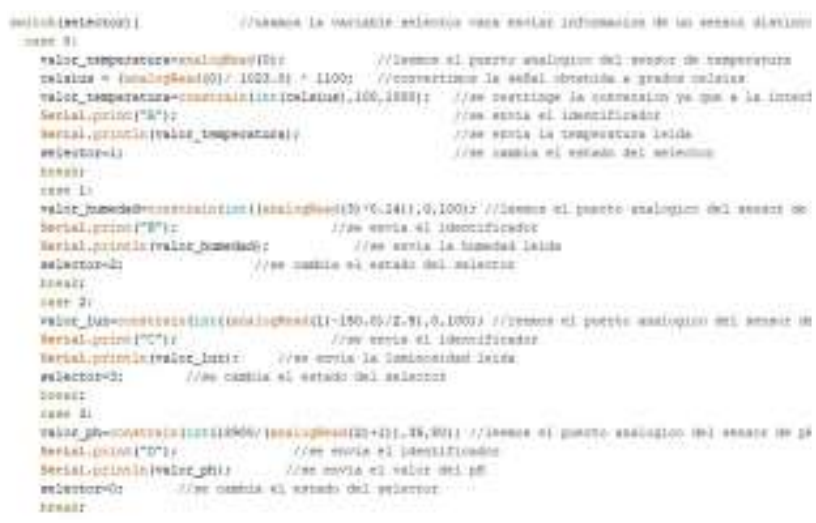

Figure 15 Part of the program that sends the reading from the sensors to the interface

The last part of the microcontroller program is in charge of counting every second that passes and activating or deactivating the corresponding actuator depending on whether it is manual or automatic configuration.

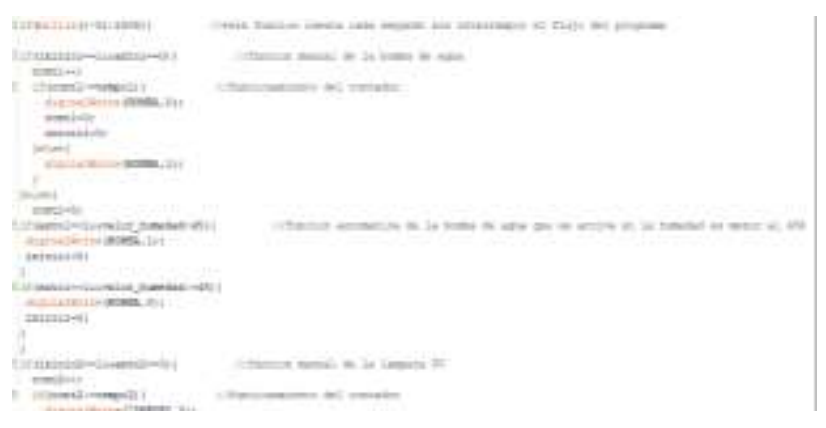

Figure 15 Automatic and manual sensors mode

\section{Interface design in Visual Basic}

The visual part of the interface, the buttons, the slider, the check boxes, the progress bars and the values to be displayed on the screen were made, as can be seen in the figure, the sensors are separated from the actuators.

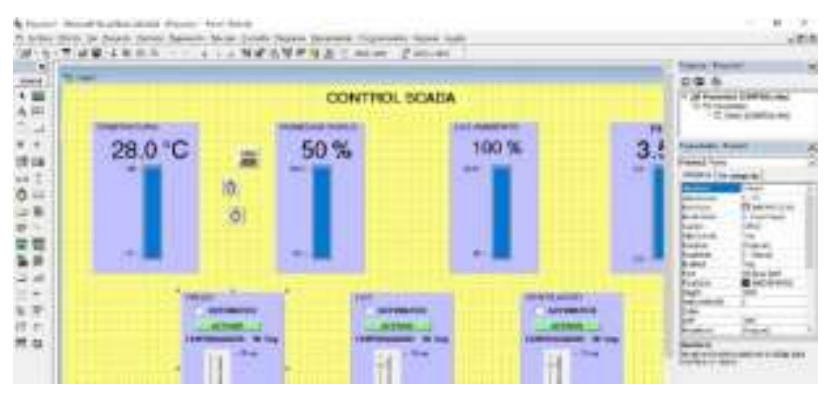

Figure 16 SCADA control graphical interface 
The communication port and the clocks that will be used to send and read information with the Arduino are added, for the case of clock 1, 250 milliseconds of waiting are added and for the case of the second clock, 350 milliseconds are added, thus adding 600 milliseconds of wait for the interface.

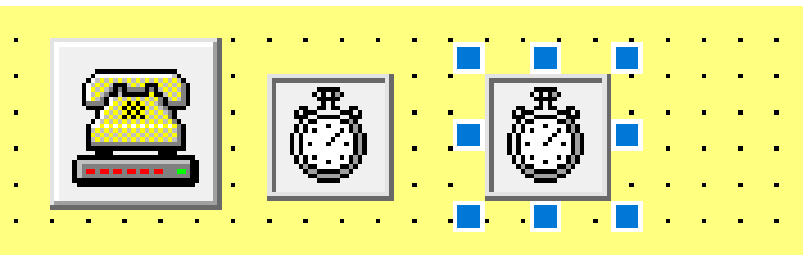

Figure 17 Communication with the Arduino and clocks

\section{Visual Basic code was made}

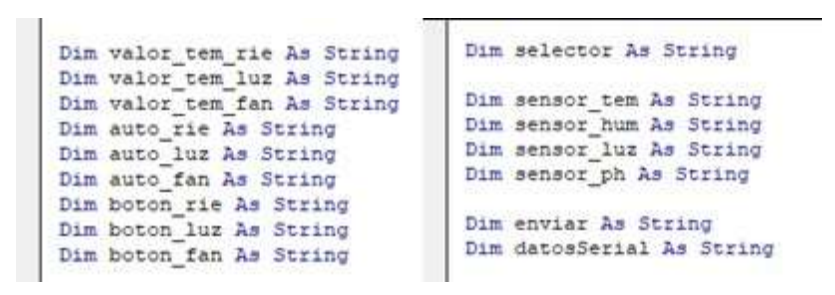

Figure 18 Declaration of the variables

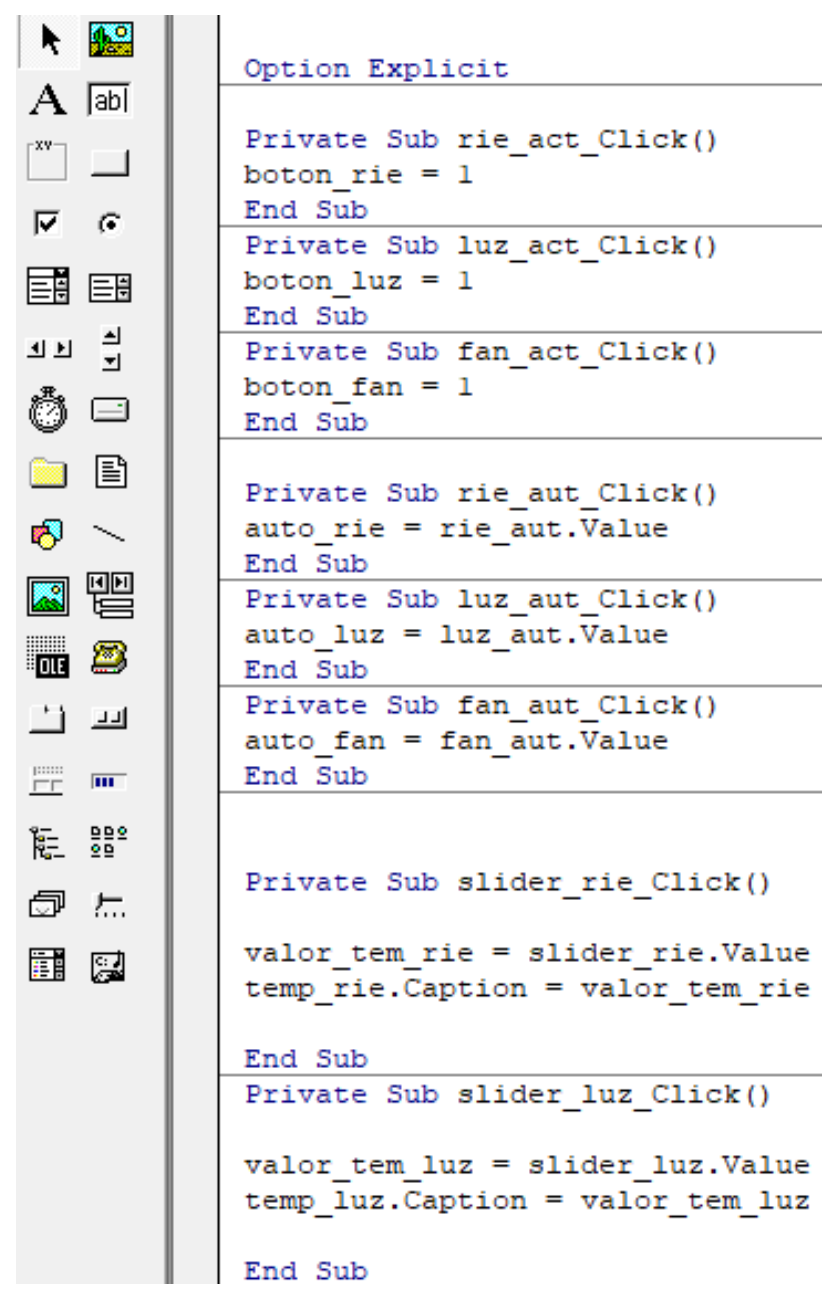

Figure 19 Function of each object
The function of each timer has been programmed, timer 1 constantly sends the status of the buttons and timers to the Arduino, each numerical value must be accompanied by an identifying letter that will help the Arduino to know what value it is.

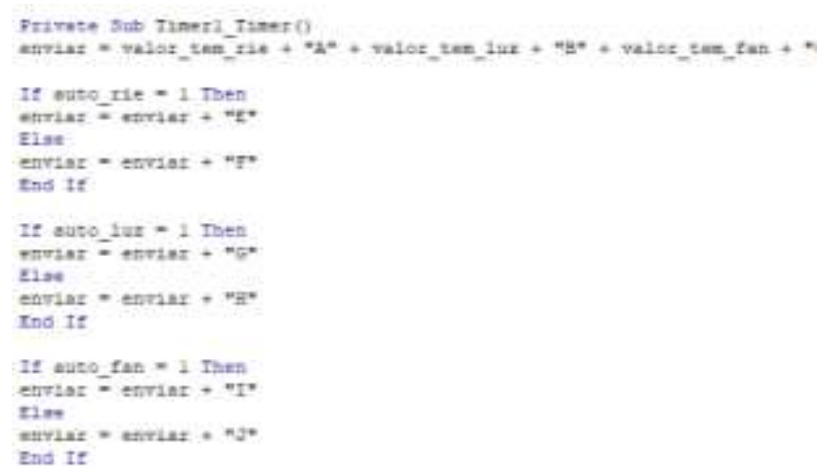

Figure 20 Sending information to the Arduino

Clock two is the one in charge of reading the information from the sensors, it has to identify which sensor it is and display its value on the screen, to do so, it must give it the format as seen.

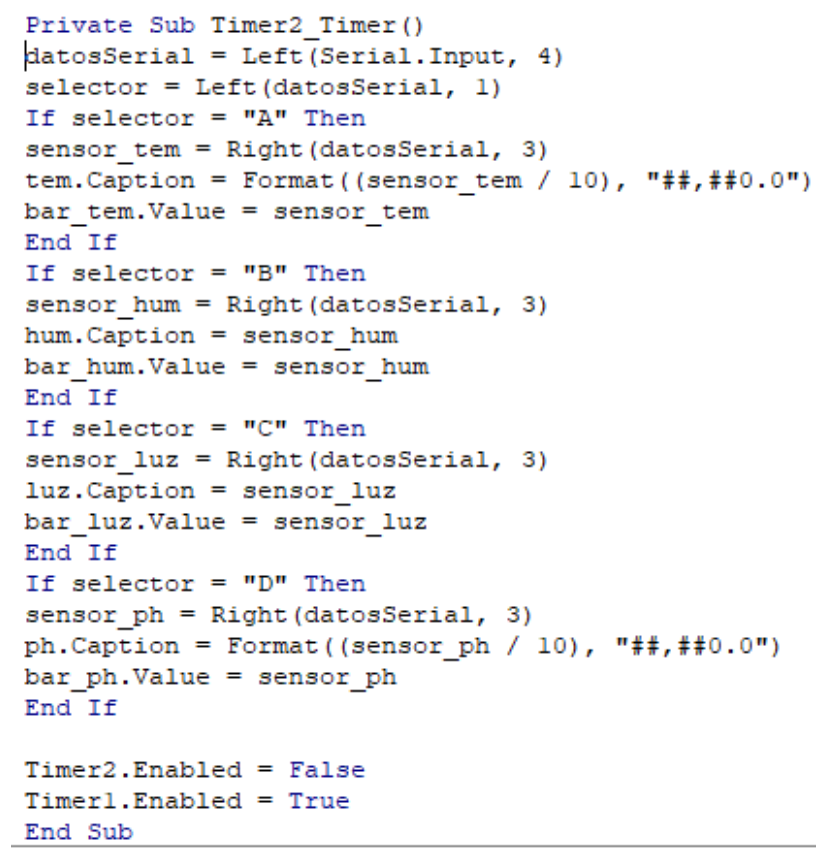

Figure 21 Sensor reading

When the interface is executed, the serial port must be configured, parameters such as communication speed and number of buffer bits, as well as the default value of some labels must be displayed. 


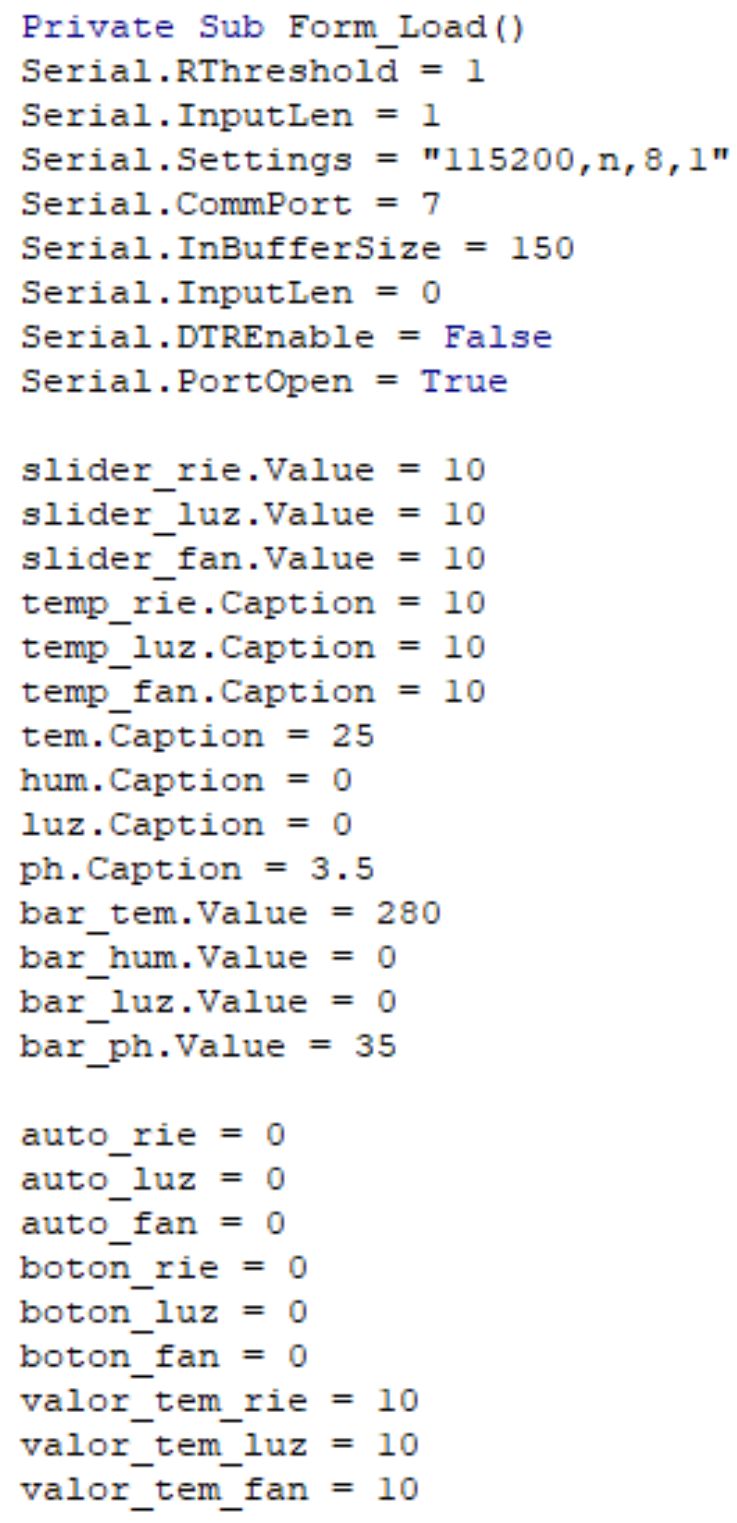

Figure 22 Configuration at the beginning of the interface execution

\section{Sensor calibration, electrical and communication tests}

During this stage the triple sensor electrode that has been disassembled was calibrated, compared to a new 3-in-1 soil meter. Different solutions are used to calibrate the $\mathrm{pH}$, one that is acidic, neutral or alkaline (lemon water, plain water and milk).

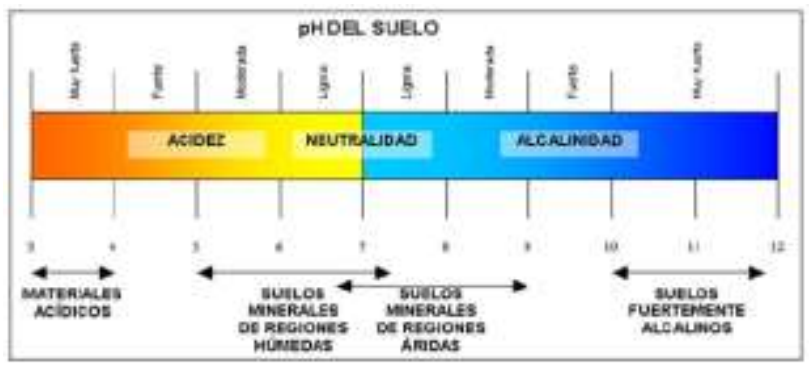

The light sensor calibration process is similar in process to that of $\mathrm{pH}$, the minimum reference point is darkness and the maximum point is the greatest amount of light delivered.

According to the LM35 sensor datasheet, every $10 \mathrm{mV}$ output is equivalent to $1^{\circ} \mathrm{C}$, so it is enough to measure the output voltage to calculate the temperature.

\section{Results}

Greenhouse and interface tests

During the period of two weeks of culture tests, the measurements of the quantitative variables of our culture (humidity, $\mathrm{pH}$, temperature and light) were obtained and are now presented by means of a results table.

\begin{tabular}{|r|r|}
$\begin{array}{c}\text { Outside Greenhouse } \\
\text { Temperature }\end{array}$ & $\begin{array}{c}\text { Temperature Inside The } \\
\text { Greenhouse }\end{array}$ \\
\hline $37^{\circ}$ & $32^{\circ}$ \\
\hline $38^{\circ}$ & $33^{\circ}$ \\
\hline $37^{\circ}$ & $32^{\circ}$ \\
\hline $39^{\circ}$ & $34^{\circ}$ \\
\hline $39^{\circ}$ & $34^{\circ}$ \\
\hline
\end{tabular}

Table 5 Results of the temperature tests inside and outside the greenhouse, already operating the SCADA system and the actuators

\begin{tabular}{|r|r|}
\hline \multicolumn{1}{|c|}{$\begin{array}{r}\text { Percentage of humidity } \\
\text { outside the greenhouse }\end{array}$} & $\begin{array}{c}\text { Percentage of humidity } \\
\text { inside the greenhouse }\end{array}$ \\
\hline $30 \%$ & $50 \%$ \\
\hline $30 \%$ & $53 \%$ \\
\hline $35 \%$ & $57 \%$ \\
\hline $38 \%$ & $58 \%$ \\
\hline $30 \%$ & $60 \%$ \\
\hline
\end{tabular}

Table 6 Results of humidity tests inside and outside the greenhouse, already operating the SCADA system and the actuators

As for the light, it was not activated during the day, because in the environment where the greenhouse was placed, the light was at its peak, sometimes if it had a lot of intensity of the sun's rays, which caused an increase in temperature, but the UV light was activated only at night. For the $\mathrm{pH}$ results, as expected, in this region, it is at the optimum. It is kept both in the greenhouse and outside, between a range of 6 and 7 on the scale, that is, our soil is sufficiently neutral and suitable for the development of our crop.

Figure 23 Soil $\mathrm{pH}$ scale

Source: Obtained from Callizaya (2015) 


\section{Sensor operation}

When conducting the greenhouse tests, we obtained that the reading of the sensors was carried out and displayed correctly in the interface. In figure 24 we can see the sensor readings displayed on the interface in real time.

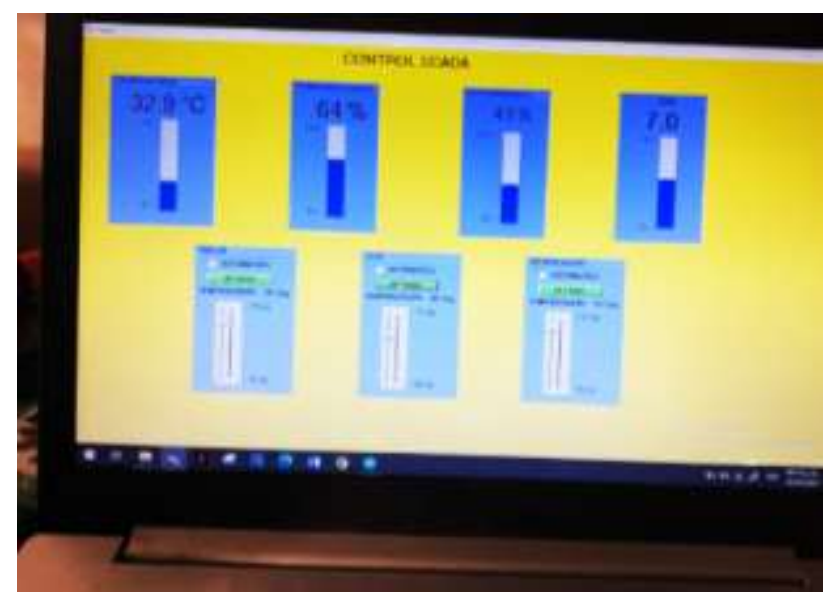

Figure 24 Results obtained from the interface

As we can see in the previous figure, the temperature was in an ideal range of $32.9^{\circ} \mathrm{C}$, as was the humidity of the soil, which at the time of reading was $64 \%$, the ambient light was $43 \%$, however, the $\mathrm{pH}$ was on the edge as the ideal range is 6.5 to 7 .

The sensors also reacted as expected to the tests, where we brought a soldering iron to the temperature sensor, and registered an increase in temperature, when watering the crops for 10 seconds the humidity increased by $5 \%$ as can be seen in the figure previous that went from $59 \%$ to $64 \%$ of soil moisture.

\section{Irrigation control}

When performing the irrigation tests with the interface, we obtained that the manual and automatic mode of the irrigation system worked correctly, as we can see in figure 83 , the drip irrigation system works with its timer in manual mode and is activated when soil moisture drops to less than $45 \%$.

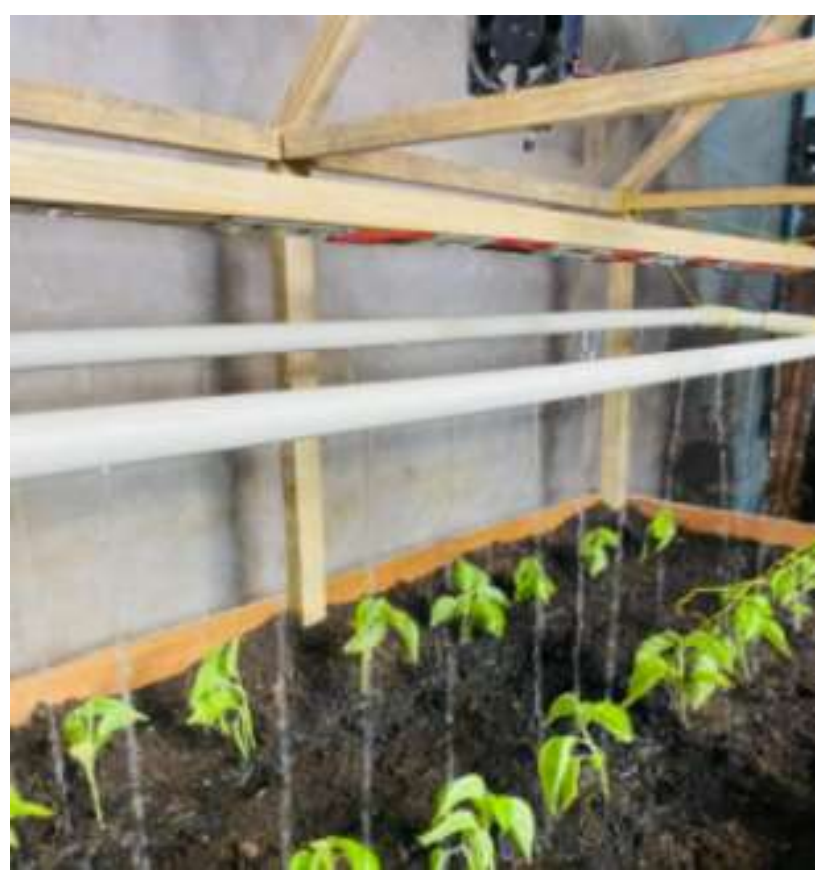

Figure 25 Irrigation system working properly

\section{Temperature control}

When we carried out the temperature tests, we had the results that the manual control of the fans works correctly with its timer and the automatic mode activates the fans when the temperature exceeds $35{ }^{\circ} \mathrm{C}$ when a soldering iron is brought close to the sensor and tries to regulate it to less than $30^{\circ} \mathrm{C} .{ }^{\circ} \mathrm{C}$ to deactivate automatically, in figure 26 we can see the operation of the fans.

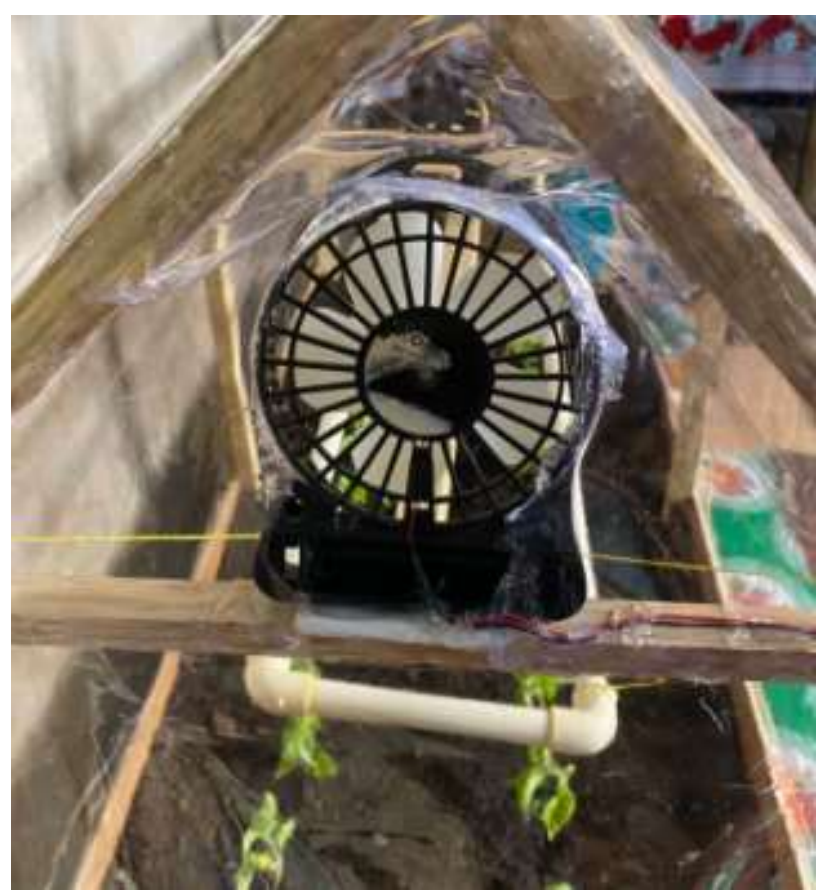

Figure 26 The fans come on after $35^{\circ} \mathrm{C}$ in automatic mode 


\section{UV lamp control}

As we can see in figure 27 , we obtained as a result a correct operation of the UV lamps, which worked with their timer in manual mode and activated when the brightness dropped to less than $15 \%$ in automatic mode.

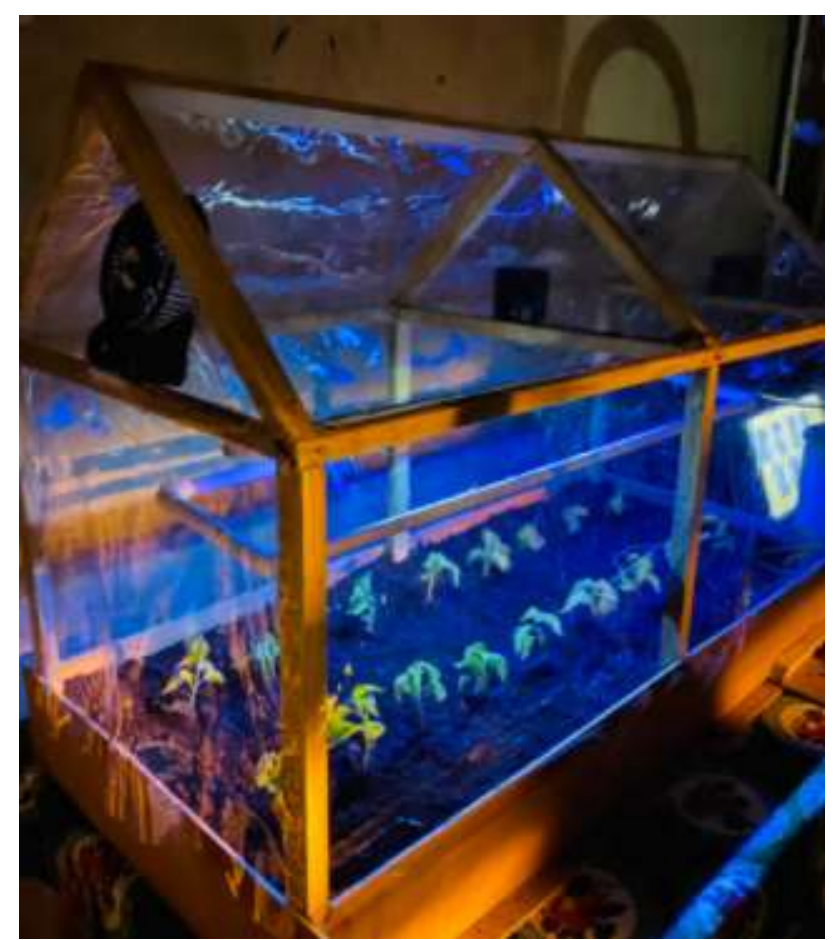

Figure 27 Operation of the ultraviolet lamp

\section{Conclusions}

It is concluded that the control systems, supervision and data acquisition, unlike the closed loop control systems that are only fed back by the sensors without being able to intervene in the process or alter the variables, SCADA systems can provide an operator from a visual interface called HMI or Human-Machine Interface.

In addition, the SCADA system implemented turned out to be very useful to acquire, monitor and control the microclimate variables in the greenhouse scale model, for this reason, with the data obtained through the tests applied during the development of this project, thinks that its application in the large-scale system may become feasible, since the automation generated by this system makes the quality of the crops more efficient, the energy consumption of the system is reduced, the labor force is reduced, costs thus increasing production.
In the future, the SCADA system could be applied in the automation of real greenhouses in the region, since it would save time, production costs and energy.

\section{References}

Callizaya, R. (2021, 21 noviembre). Guía para muestreo de suelo. Todo sobre suelos agrícolas. http://istaic.blogspot.com/2015/10/

Corrales, L. (2007, diciembre). Sistemas Scada. https://bibdigital.epn.edu.ec/bitstream/15000/10 020/2/PARTE\%202.pdf

FAO. (1994). El nivel de adaptabilidad de la base de datos de requisitos ambientales de cultivos de la FAO. Roma, Italia.

Hernández, M. (2013). Invernadero Inteligente con PLC's. SOMI XXVII. Congreso de instrumentación.

Jensen, M. (1995). Agricultura protegida una revisión global. Washington, USA.

Macías, H., Romero, E. and Martínez, J. (2003) Invernaderos de Plástico. In: Cohen, I.S., Ed. Agricultura Protegida.

Organización de las Naciones Unidas para la Agricultura y la Alimentación - Secretaria de Agricultura Ganadería, Desarrollo Rural, Pesca y Alimentación (FAO - SAGARPA). (2007) Producción de hortalizas a cielo abierto y bajo condiciones protegidas. México. www.sagarpa.gob.mx/pesa/docs_pdf/proyectos _tipo/invernaderos.pdf.

Pérez-López, L. (2014, 26 noviembre). Los sistemas SCADA en la automatización industrial. Tecnología en Marcha, 28(4). https://dialnet.unirioja.es/descarga/articulo/528 0242.pdf

Ramírez, M. (2006). Potencial de producción del chile habanero en el sur de Tamaulipas. México: INIFAP.

Reséndez, M. (2011). Características de la agricultura protegida y su entorno en México. Revista Mexicana de Agronegocios, 29. https://www.redalyc.org/pdf/141/14119052014. pdf 